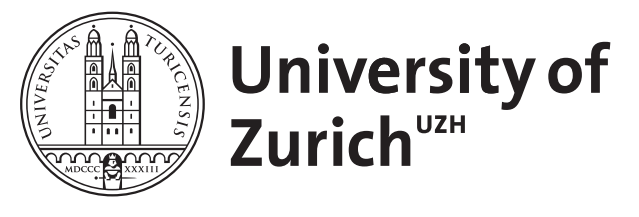

\title{
Controlling ambiguities in legislative language
}

Bünzli, Alexandra ; Höfler, Stefan

\begin{abstract}
Legislative language exhibits some characteristics typical of languages of administration that are particularly prone to eliciting ambiguities. However, ambiguity is generally undesirable in legislative texts and can pose problems for the interpretation and application of codified law. In this paper, we demonstrate how methods of controlled natural languages can be applied to prevent ambiguities in legislative texts. We investigate what types of ambiguities are frequent in legislative language and therefore important to control, and we examine which ambiguities are already controlled by existing drafting guidelines. For those not covered by the guidelines, we propose additional control mechanisms. Wherever possible, the devised mechanisms reflect existing conventions and frequency distributions and exploit domain-specific means to make ambiguities explicit.
\end{abstract}

DOI: https://doi.org/10.1007/978-3-642-31175-8_2

Posted at the Zurich Open Repository and Archive, University of Zurich ZORA URL: https://doi.org/10.5167/uzh-62061

Book Section

Published Version

Originally published at:

Bünzli, Alexandra; Höfler, Stefan (2012). Controlling ambiguities in legislative language. In: Rosner, Mike; Fuchs, Norbert E. Controlled Natural Language - Second International Workshop, CNL 2010. Berlin: Springer, 21-42.

DOI: https://doi.org/10.1007/978-3-642-31175-8_2 


\title{
Controlling Ambiguities in Legislative Language
}

\author{
Alexandra Bünzli and Stefan Höfler \\ Institute of Computational Linguistics, University of Zurich \\ \{buenzli, hoefler\}@cl.uzh.ch
}

\begin{abstract}
Legislative language exhibits some characteristics typical of languages of administration that are particularly prone to eliciting ambiguities. However, ambiguity is generally undesirable in legislative texts and can pose problems for the interpretation and application of codified law. In this paper, we demonstrate how methods of controlled natural languages can be applied to prevent ambiguities in legislative texts. We investigate what types of ambiguities are frequent in legislative language and therefore important to control, and we examine which ambiguities are already controlled by existing drafting guidelines. For those not covered by the guidelines, we propose additional control mechanisms. Wherever possible, the devised mechanisms reflect existing conventions and frequency distributions and exploit domain-specific means to make ambiguities explicit.
\end{abstract}

\section{Introduction}

In many respects, legislative drafting constitutes an obvious field of application for controlled natural languages. Legislative texts are produced in a well-defined work process and go through several editorial cycles. Government agencies have devised drafting guidelines meant to ensure the quality of the texts, especially with regard to clarity and readability. To a certain extent, legislative language is therefore already controlled. In this paper, we focus on Swiss legislative texts written in German. Although most countries and legal systems face similar problems when drafting legislation, the conventions and work processes differ substantially from country to country. As a country with a long tradition in legislative drafting, Switzerland has established a well-defined work cycle in which every federal legislative text is edited by a specialized institution: the Federal Chancellery's Central Language Services [15]. This process aims at ensuring consistency between the different language versions of a law, as each of the language versions is considered equally authentic and legally binding. This has led to relatively detailed instructions and well-written legislative texts [11].

However, existing drafting guidelines [2625615218] offer little or no advice on how ambiguity must be controlled - beyond stating that, whenever possible, it is to be avoided altogether. But due to some of its peculiarities, legislative language is particularly prone to exhibit certain types of ambiguity. Like most languages of administration, legislative language uses a style of writing using complex nominals, which elicits a range of ambiguous constructions. Long and 
complex noun phrases that are complemented with attributive adjectives or participles, genitive attributes or prepositional phrases generate a high number of attachment ambiguities. The frequent use of light verb constructions, which normally combine a verb with a prepositional phrase, further increases this number. Moreover, the use of plurals instead of gender-specific singular forms, which is also typical of contemporary legislative writing, is a prolific source of semantic ambiguities.

Ambiguous constructions can pose a problem for the interpretation and application of a legislative text. In the light of this fact, it is particularly unfortunate that ambiguities are not always easy to detect for human editors. Since humans unconsciously activate contextual knowledge when reading a text, they easily overlook ambiguities and secondary interpretations that could become relevant in a specific case. But ambiguities that go unnoticed in the drafting process can later cause uncertainties with regard to the correct application of a statute or regulation 1

In this paper, we show that the methods of controlled natural language can provide means to tackle this problem. We first present the specific approach we have developed for this particular task (section 2). We then give a brief overview of the types of ambiguities that are already controlled by existing drafting guidelines and of those that are frequent in legislative language but still lack control (section 3). We then illustrate how these latter types of ambiguity - specifically attachment and plural ambiguity - can be controlled by applying the proposed methods (section 4). We conclude with a brief summary of our approach (section 5).

\section{Approach}

Controlled natural languages are artificially designed subsets of natural languages. Occasionally, a distinction is made between human-oriented controlled natural languages and computer-oriented controlled natural languages [1830 20|22]. Human-oriented controlled natural languages aim to improve the readability and translatability of technical documents [2235214]; computer-oriented controlled natural language are meant to serve as interfaces to some sort of formal logical representation 928733 .

One main task of both classes of controlled natural languages is the reduction of natural language ambiguity. While human-oriented controlled natural languages usually focus on lexical ambiguities, simple sentence constructions and pragmatic issues, computer-oriented controlled natural languages aim at completely unambiguous constructions, which can be automatically translated into a formal representation. They approach this task by either allowing only specific constructions (e.g. prohibiting the use of ambiguous constructions) or by

${ }^{1}$ For an example of how attachment ambiguity can cause a legal dispute see the Appellate Court of Illinois, Regency Commercial Assocs., LLC v. Lopax, Inc., 2007 Ill. App. LEXIS 476 (Ill. App. Ct. May 4, 2007). 
assigning them a default interpretation and providing paraphrases for the other readings.

We have adopted these methods to reduce ambiguity in legislative texts. While some research has looked into the applicability of computer-oriented controlled natural languages to the legal domain 1910, the work presented in this paper focuses on a human-oriented perspective. We therefore do not assign a formal representation. Our aim is rather to systematically refine existing drafting guidelines by developing specific additional rules that deal with as yet uncontrolled types of ambiguity. Our approach builds on [12] and [3], who propose to control ambiguities by exposing the author or editor of a text to explicit paraphrases for the individual readings of an ambiguous construction.

We propose a three-step procedure:

\section{Conventional wording $(\mathbf{C})$}

In a first step, drafters phrase the text they want to write within the boundaries defined by a set of construction rules. Such rules define which constructions are allowed and which are prohibited. They may also prescribe that a specific ambiguous constructions is only to be used in one particular sense - thus taking the role of what is usually called an interpretation rule in the context of controlled natural language.

The requirement of usability demands that the rules we develop closely resemble conventional legislative language: drafters will only be able and willing to apply a controlled version of legislative language if it is not significantly different from what they have been used to. Its rules thus have to be designed to mimic (i) the pragmatics of the text domain, (ii) historically accrued conventions, iii) frequency distributions present in legislative texts, as well as (iv) standards defined in existing drafting guidelines.

The problem with the requirement of conventionality is that users not familiar with the rules and standards applied will still find many constructions ambiguous - and likewise, drafters may still overlook such instances of ambiguity or use ambiguous constructions in a sense other than the one suggested by the rules.

2. Explicit paraphrase $(\mathbf{E})$

To tackle this problem, we define paraphrases that can be constructed deterministically (either by hand or automatically) from the ambiguous constructions of the conventional form. These paraphrases make the interpretation the constructions would obtain according to the rules explicit. Drafters can use this explicit form of the same text to verify if the interpretation they intended complies with the usage suggested by the standard. They are thus pointed to ambiguities they may have overlooked otherwise.

As they serve the purpose of visualization only, the explicit paraphrases do not have to resemble conventional legislative language (or even sound natural). Where it is not possible to make a specific reading explicit by using the means of natural language only, they resort to non-linguistic means (e.g. brackets) to achieve the task. 


\section{Recommended wording $(\mathbf{R})$}

The recommended version proposes a wording which is as explicit as possible while still sounding natural. Like the explicit version, it can be constructed deterministically from the conventional form. As the name suggests, it is a recommendation and represents the wording the drafter should usually choose. Depending on the constructions used, the recommended version may be identical to the original conventional wording or to the explicit paraphrase.

However, we let the drafter decide which version he adopts for the final document: the recommended, the conventional or even the explicit version if it does not use any non-linguistic means. Often, ambiguous constructions are automatically disambiguated through contextual and world knowledge and it is not necessary to use the most explicit version: as they choose from the different versions, drafters can adapt to the specific situation, taking into consideration the clearness and readability of the sentence at hand and the text as a whole.

The following example will serve as an illustration of our approach:

(1) C: Die Kantone können Fachhochschulen einrichten. Sie werden selbstständig geleitet.

'The cantons may establish technical universities. They are governed autonomously.'

E: [Die Kantone $]_{1}$ können Fachhochschulen einrichten. [Sie $]_{1}$ werden selbstständig geleitet.

'[The cantons $]_{1}$ may establish technical universities. [They $]_{1}$ are governed autonomously.'

R: Die Kantone können Fachhochschulen einrichten. Die Kantone werden selbstständig geleitet.

'The cantons can establish technical universities. The cantons are governed autonomously.'

We have adopted this example from a drafting guideline of the canton of Zurich 21. The drafting guideline states that sentences can only be introduced with a pronoun if the pronoun refers to the subject of the immediately preceding sentence. We have incorporated this as a drafting rule. The explicit version $(\mathbf{E})$ makes the interpretation explicit that the drafted conventional version $\mathbf{C}$ would obtain if it complied to the drafting rule: the pronoun sie ('they') would refer to die Kantone ('the cantons'). It thus allows the drafter to verify if this is the intended interpretation. The recommended version $(\mathbf{R})$ does not use a pronoun. This is due to the fact that this specific rule does not prevent ambiguity per se: although the drafting rule theoretically prevents ambiguous readings, for a reader not familiar with the rule, the sentence remains ambiguous in situations where, as it is the case in example (2), another suitable referent exists. In such cases, the drafter should either choose the recommended version or - realizing this interpretation is not what he intended to say - rephrase the passage and make Fachhochschulen ('technical universities') the subject of the second sentence. 
In example (1) the explicit version used non-linguistic means such as indexes and brackets to visualize the interpretation. Example $(2)$ shows a case where the interpretation can be made explicit without such non-linguistic means:

C: Die Parteivertreter und -vertreterinnen haben sich durch eine Vollmacht auszuweisen.

'The party representatives have to identify themselves with a letter of attorney.'

E: Jeder Parteivertreter und jede Parteivertreterin hat sich durch eine Vollmacht auszuweisen.

'Each party representative has to identify himself with a letter of attorney.'

$\mathbf{R}$ : Die Parteivertreter und -vertreterinnen haben sich durch eine Vollmacht auszuweisen.

'The party representatives have to identify themselves with a letter of attorney.'

Before we further explicate this approach, we shortly discuss in what way legislative language is already controlled through drafting guidelines and which constructions are not controlled yet although they are frequent in legislative language and potentially pose problems. In section 4 of the paper, we will then discuss a number of real-case examples, the issues that arise in them and the design decisions one has to make.

\section{Status Quo in Legislative Drafting}

In natural language, ambiguities exist on various levels: there is lexical, syntactic and semantic ambiguity as well as ambiguity on the pragmatic and discourse level. Governments have designed drafting guidelines that aim at ensuring the comprehensibility of legislative texts and thus, among other things, try to control some of these ambiguities.

These guidelines are - as the name indicates - mere recommendations and have no absolute force. The control is therefore on a quite abstract level and there is always a chance that an ambiguous structure could slip through the editing process and be then constituted in the law 3 There is no systematic or technical process to ensure compliance with the drafting guidelines.

Not every type of ambiguity gets the same amount of attention in the existing drafting guidelines for legislative texts. In the remainder of this section, we will thus give a brief overview of (i) the types of ambiguity that existing Swiss drafting guidelines [26 25/6 21] deal with and (ii) those that are particularly frequent in legislative texts but as yet lack control.

${ }^{2}$ Example from Art. 40 Abs. 2 BGG.

${ }^{3}$ It is not to be forgotten that legislative texts are written for humans and a lot of ambiguities can be resolved through external knowledge such as situational knowledge or world knowledge. 


\subsection{Ambiguities Controlled by Existing Drafting Guidelines}

Lexical ambiguity is probably the type of ambiguity that legal experts are most aware of. As in every technical language, the use of exact terminology is essential; it is therefore not surprising that lexical ambiguity is the most controlled type of ambiguity in the legal domain. Vast terminological databases exist, which are especially important for interlingual and international translations and communications. The same technical terms are often used quite differently by the different governments, which makes a semantically correct translation very hard and terminological control paramount. There is no controlled vocabulary in the strict sense - the domain is too broad - but the use of specific words is regulated, and existing drafting guidelines demand that terms have to be used consistently and that, in order to avoid confusion, new or unclear terms have to be defined in the regulation itself.

Syntactic ambiguity is not controlled explicitly. There is no real awareness of the peculiarities of syntactic ambiguity among legal experts. However, certain drafting guidelines indirectly control syntactic ambiguity: they state e.g. that sentences should be short and concise and default sentence patterns should be preferred. The last point is especially important as German has a relatively free word order and agreement information is not always sufficient to unambiguously identify the correct structure, as the following example from the drafting guidelines of the canton of Zurich [21] demonstrates:

Die Bewilligung erteilt das Amt.

Interpretation 1: 'The permission grants the department.'

Interpretation 2: 'The department grants the permission.'

In example (3), it is not clear which noun phrase constitutes the subject and which the object. Syntactically, both interpretations are valid; semantically, the second interpretation is clearly to be preferred. The sentence would be a lot easier to understand if it followed the default sentence pattern subject $\triangleright$ verb $\triangleright$ objects (Das Amt erteilt die Bewilligung) and thus actively support the correct interpretation.

Another rule in existing guidelines demands that nominalizations should be avoided. This rule is mainly designed to improve readability, but it also prevents thematic ambiguities, which can arise from nominalizations of transitive verbs that are accompanied by a genitive attribute. A classical example is die Untersuchung der Behörde ('the inspection of the agency'), which does not specify if the agency inspects or if it is itself the object of the inspection.

Other drafting guidelines suggest that complex sentences are formalised as enumerations, a tool which is very frequently used in Swiss legislative language. As complex sentences are more likely to contain attachment ambiguities, this rule can also contribute to a reduction of ambiguity in a text.

Like syntactic ambiguity, semantic ambiguity is not controlled explicitly. But there are some isolated rules which deal with semantic problems such as (i) pronoun resolution and (ii) conjunctive vs. disjunctive enumerations. An existing rule to control pronoun resolution has already been discussed in section 2 
above. The problem posed by ambiguities relating to conjunctive vs. disjunctive readings of enumerations can be illustrated with the following example from a regulations on weapons and ammunition 4

(4) Messer gelten als Waffen, wenn sie:

a. einen einhändig bedienbaren Spring- oder anderen automatischen Auslösemechanismus aufweisen;

b. geöffnet insgesamt mehr als $12 \mathrm{~cm}$ lang sind; und

c. eine Klinge haben, die mehr als $5 \mathrm{~cm}$ lang ist.

'Knives count as weapons if they

a. are equipped with a switchblade mechanism or any other automatic trigger that can be operated with one hand;

b. are at least $12 \mathrm{~cm}$ long when opened; and

c. have a blade that is at least $5 \mathrm{~cm}$ long.'

Enumerations can be interpreted as conjunctions or as disjunctions. Legal experts are very much aware of this kind of ambiguity. Existing drafting rules state that, if the intended reading is not clear from the context, the conjunctive or disjunctive nature of an enumeration has to be made explicit: by inserting und ('and') for a conjunctive reading or oder ('or') for an disjunctive reading after the second last item. In example (4), und is thus required, as the enumeration could otherwise be misinterpreted as a disjunction and consequently be applied to more types of knives than actually intended.

\subsection{Ambiguities Not Controlled by Existing Guidelines}

While existing guidelines do control ambiguities to a certain extent, there are at least two types of ambiguity that are not covered even though they are prevalent in legislative texts and can give rise to severe misinterpretations: attachment ambiguity and plural ambiguity.

Attachment ambiguities frequently arise when noun phrases in object positions are followed by prepositional phrases, or when complex noun phrase coordinations are accompanied by an attribute (a preceding adjective or participle, a postpositional prepositional phrase or a relative clause). In the latter case, it is often unclear if the attribute modifies the whole coordinated structure or only the nearest element 16. Example (5) shows how such an attachment ambiguity can lead to a legal dispute.

(5) Seller will not after the date of this agreement sell, lease or permit to be occupied any real estate which Seller owns, manages or otherwise controls within one mile of the Land for the purpose of constructing, or having conducted thereon, any fast food [...] restaurant or restaurant facility whose principal food product is chicken on the bone, boneless chicken or chicken sandwiches.

\footnotetext{
${ }^{4}$ Art. 7 Abs. 1, SR 514.541, Verordnung über Waffen, Waffenzubehör und Munition, Stand am 12. Dezember 2008.
} 
The above passage of a contract was the cause for a dispute which the Illinois appellate court had to decide 5 The problem was caused by the uncertain attachment of fast food 6 Does it only modify restaurant or restaurant facility as well? Is a restaurant that is not a fast food restaurant, but serves primarily chicken, permitted? It would be if fast food modifies both restaurant or restaurant facility, but it would not, if it only modifies restaurant. This ambiguity resulted in a two year dispute and illustrates how important the controlling of attachment ambiguities in legislative texts can be.

The frequency of plural ambiguities has especially increased with the introduction of gender neutral formulations. To facilitate grammatical agreement with other constituents of a sentence, existing drafting guidelines suggest that genderneutral plural forms are used instead of coordinations of gender-marked singular forms. The following (slightly adapted) example from the drafting guidelines of the canton of Zurich [21] illustrates this point:

(6) Der Lehrer oder die Lehrerin sorgt für die zweckdienliche Einrichtung seines oder ihres Schulzimmers. Er oder sie wird angehört, bevor die Schulpflege bauliche Massnahmen beschliesst.

'The teacher takes care of the appropriate equipment of his or her class room. He or she will be heard before the School Board decides on constructional measures.'

If the subject of the first sentence is transformed into a plural, the anaphoric reference at the beginning of the second sentence becomes less cumbersome:

Die Lehrerinnen und Lehrer sorgen für die zweckdienliche Einrichtung ihrer Schulzimmer. Sie werden angehört, bevor die Schulpflege bauliche Massnahmen beschliesst.

'The teachers take care of the appropriate equipment of their class rooms. They will be heard before the School Board decides on constructional measures.'

The problem is that by transforming the subject into plural, a new instance of ambiguity is created, which yields two additional interpretations: it is now unclear if, before any construction measure is taken, all the teachers have to be heard as a group, or if every teacher has to be heard individually, or if only the teacher of the class room concerned has to be heard.

Due to their relative frequency and their potential to cause misinterpretations, attachment ambiguity and plural ambiguity clearly pose a problem for legislative texts.

${ }^{5}$ Case: Appellate Court of Illinois, Regency Commercial Assocs., LLC v. Lopax, Inc., 2007 Ill. App. LEXIS 476 (Ill. App. Ct. May 4, 2007), retrieved from a legal blog: http://www . adamsdrafting.com/2007/05/15/illinois-syntactic-ambiguity/ at March 10, 2011.

${ }^{6}$ There is another attachment ambiguity in the sentence: the relative sentence at the end of the passage could modify only restaurant facility or both restaurant and restaurant facility, but this was not questioned, neither by the involved parties nor by the court. 


\section{Proposed Rules}

In the following sections, we will demonstrate how the methods introduced in section 2 can be applied to control attachment ambiguity and plural ambiguity.

\subsection{Controlling Attachment Ambiguity}

As already mentioned above, one of the most common causes for attachment ambiguity are prepositional phrases modifying a verb or a noun phrase coordination. A study on Italian and English legislative texts carried out by Venturi [34] shows that prepositional phrases are particularly frequent in legislative texts. Similarly, Nussbaumer [17. points out that Swiss legal language is characterized (among other things) by a relatively high frequency of prepositional phrases. He speculates that this characteristic emerges from a conflict between the need to be brief and the need to provide all important information. Therefore, the attachment of prepositional phrases deserve special attention in the drafting process.

We will explain our approach to controlling the attachment ambiguity they can cause with the following example from the Federal Supreme Court Act:7

(8) Das Bundesgericht deckt seinen Bedarf an Gütern und Dienstleistungen im Bereich der Logistik selbständig.

'The Federal Supreme Court covers its need for goods and services in the sector of logistics autonomously.'

The example shows a short sentence with two prepositional phrases. While the prepositional phrase an Gütern und Dienstleistungen depends on Bedarf and thus has to follow right after it, the attachment of the prepositional phrase $\mathrm{im}$ Bereich der Logistik constitutes a typical case of attachment ambiguity [10]. There are four possible antecedents to which it could theoretically attach: (a) deckt, (b) Güter und Dienstleistungen, (c) Dienstleistungen and (d) Bedarf. The respective four readings of the sentence are shown below, with the prepositional phrase put in italics and the antecedent underlined:

(9) a. Das Bundesgericht deckt seinen Bedarf an Gütern und Dienstleistungen im Bereich der Logistik selbständig.

b. Das Bundesgericht deckt seinen Bedarf an Gütern und Dienstleistungen im Bereich der Logistik selbständig.

c. $\overline{\text { Das Bundesgericht deckt seinen Bedarf an Gütern und Dienstleis- }}$ tungen im Bereich der Logistik selbständig.

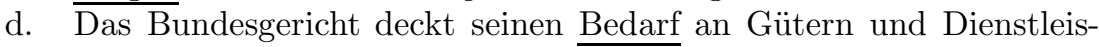
tungen im Bereich der Logistik selbständig.

To get an idea of how these ambiguities are best controlled, we investigated (i) under what conditions the attachment of the prepositional phrase would not be ambiguous and (ii) how prepositional phrases that modify coordinated structures (or components thereof) are prevalently used in legislative texts.

${ }^{7}$ Art. 25a Abs. 2, Bundesgerichtsgesetz (BGG) of June 17, 2005 (status January 1, 2011). 
With regard to (i), we found that the attachment of the prepositional phrase is highly ambiguous as long as the prepositional phrase follows a noun phrase; if the prepositional phrase directly follows the verb, only one attachment is possible. In order to study (ii), we syntactically annotated a small corpus consisting of two texts: the Federal Supreme Court Act (Bundesgerichtsgesetz, BGG) and the Ordinance of the University of Zurich 8 The corpus consists of a total of 1,124 sentences (Federal Supreme Court Act: 776 sentences, Ordinance of the University of Zurich: 348 sentences). We specifically looked at coordinated noun phrases which are directly followed by a prepositional phrase. That is, we looked at constructions in which the prepositional phrase was either attached to a coordinated phrase or attached to the last element of a coordination. We found 52 attachments to the coordinated phrase and 39 attachments to the last element of the coordination. Of the 39 attachments to the last element of a coordination, 9 were formulated according to our Rule 2 (see below); another 9 were formulated according to Rule 3 , in 6 cases, the noun selected the preposition (valency information); in another 7 cases, semantics favored this attachment clearly; in 6 cases, the attachment was undecidable; and in the remaining 2 cases, some special construction prohibited the attachment to the whole coordinated phrase. On the basis of these findings, we have constructed new drafting rules (Rules 1 to 5 below).

Our first rule is a general instruction on where to attach constituents:

\section{Rule 1. Attach to the nearest constituent}

A prepositional phrase should only be attached to the nearest possible antecedent. If that antecedent is a coordinated phrase, the prepositional phrase should only be used if it refers to the whole coordinated phrase rather than to its last conjunct.

Had sentence (8) been constructed according to this rule, reading (9-b) would be its correct interpretation. Example (10) illustrates the explicit paraphrase and the recommended wording that we defined for the rule.

(10) C: Das Bundesgericht deckt seinen Bedarf an Gütern und Dienstleistungen im Bereich der Logistik selbständig.

'The Federal Supreme Court supplies its need for goods and services in the sector of logistics autonomously.'

E: Das Bundesgericht deckt seinen Bedarf an [ [ Gütern und Dienstleistungen ] im Bereich der Logistik ] selbständig.

'The Federal Supreme Court supplies its need for [ [ goods and services ] in the sector of logistics ] autonomously.'

R: Das Bundesgericht deckt seinen Bedarf an Gütern und Dienstleistungen im Bereich der Logistik selbständig.

'The Federal Supreme Court supplies its need for goods and services in the sector of logistics autonomously.'

$\overline{8}$ State: May 2010. 
The explicit paraphrase uses brackets to visualize the attachment of the prepositional phrase. This non-linguistic means appears to be the simplest and most comprehensible way to achieve the task. Alternatively, one could define an explicit version as shown in (11) where no non-linguistic means are used:

E: Das Bundesgericht deckt seinen Bedarf an Gütern im Bereich der Logistik und Dienstleistungen im Bereich der Logistik selbständig. 'The Federal Supreme Court supplies its need for goods in the sector of logistics and services in the sector of logistics autonomously.'

This alternative paraphrase could actually be used in legislative texts, if one wanted to be as clear as possible. However, due to the repetitions, it sounds cumbersome and is not recommended for use. Since there is no straightforward way of making the conventional reading more explicit, the recommended wording shown in (10) is identical to the original text.

To express the other three interpretations, the sentence has to be rephrased. Reading (9-a) for instance, can be obtained by placing the prepositional phrase right after the verb:

C: Das Bundesgericht deckt im Bereich der Logistik seinen Bedarf an Gütern und Dienstleistungen selbständig.

'The Federal Supreme Court covers, in the sector of logistics, its need for goods and services autonomously.'

E: Das Bundesgericht [ deckt im Bereich der Logistik ] seinen Bedarf an Gütern und Dienstleistungen selbständig.

'The Federal Supreme Court [ covers, in the sector of logistics, ] its need for goods and services autonomously.'

R: Das Bundesgericht deckt im Bereich der Logistik seinen Bedarf an Gütern und Dienstleistungen selbständig.

'The Federal Supreme Court covers, in the sector of logistics, its need for goods and services autonomously.'

Here, the recommended wording is the same as the conventional version because the conventional wording is both natural and unambiguous. The explicit paraphrase would thus actually not be needed. We provide a version with brackets anyway to visualize the attachment for verification purposes and to raise awareness of potential ambiguities in the drafter.

Reading (9-c) can be obtained by switching the order of the two conjuncts and placing the prepositional phrase right after the new first conjunct (Dienstleistungen):

(13) C: Das Bundesgericht deckt seinen Bedarf an Dienstleistungen im Bereich der Logistik und Gütern selbständig.

'The Federal Supreme Court covers its need for services in the sector of logistics and (for) goods autonomously.'

E: Das Bundesgericht deckt seinen Bedarf an [ Dienstleistungen im Bereich der Logistik ] und Gütern selbständig.

'The Federal Supreme Court covers its need for [ services in the sector of logistics ] and (for) goods autonomously.' 
R: Das Bundesgericht deckt seinen Bedarf an Dienstleistungen im Bereich der Logistik sowie an Gütern selbständig.

'The Federal Supreme Court covers its need for services in the sector of logistics as well as for goods autonomously.'

As before, the conventional wording is not ambiguous; the explicit version simply serves the purpose of verification. But in contrast to the previous examples, the recommended version differs from the conventional wording: on the one hand, it suggests that the preposition an is repeated with the second conjunct; on the other hand, the conjunction sowie ('as well as') replaces und ('and') to make the structure of the sentence clearer.

The recommended version indicates that reading (9-c) can also be obtained by exploiting another convention that already exists in legislative language: the binding provided by the conjunction sowie ('as well as') is weaker than that of the conjunction und ('and'). We have constructed an actual drafting rule on the basis of this implicit convention 10

\section{Rule 2. Use sowie and oder aber as barriers}

The conjunctions sowie and oder aber can be used instead of und and oder respectively to introduce a barrier into a coordinated phrase in order to prevent attachment to the elements on the other side of the barrier.

Example (14) shows how this rule can be applied to express reading (9-c) it is now not necessary anymore to switch the order of the conjuncts:

C: Das Bundesgericht deckt seinen Bedarf an Gütern sowie Dienstleistungen im Bereich der Logistik selbständig.

'The Federal Supreme Court covers its need for goods as well as services in the sector of logistics autonomously.'

E: Das Bundesgericht deckt seinen Bedarf an Gütern sowie [ Dienstleistungen im Bereich der Logistik ] selbständig.

'The Federal Supreme Court covers its need for goods as well as [ services in the sector of logistics ] autonomously.'

R: Das Bundesgericht deckt seinen Bedarf an Gütern sowie an Dienstleistungen im Bereich der Logistik selbständig.

'The Federal Supreme Court covers its need for goods as well as for services in the sector of logistics autonomously.'

Example (14) expresses the same meaning as (13) but the order in which the conjuncts are arranged make it sound more natural. This is due to the fact that, in natural language, longer elements tend to be placed at the end of a list.

\footnotetext{
${ }^{9}$ In the German version, Logistik and Gütern cannot be coordinated due to case agreement. However, the English version is ambiguous: it is unclear if 'goods' is coordinated with 'services' or 'logistics'.

${ }^{10}$ Our drafting rule was also discussed at a meeting of the German section of the Federal Chancellery's Central Language Services 4].
} 
Again, the recommended wording suggests that the preposition an is repeated. Like the use of sowie, the repetition of shared components is a common technique to introduce a barrier into a coordinated phrase in order to prevent attachment to the elements on the other side of the barrier. We have cast a new drafting rule that reflects this phenomenon:

\section{Rule 3. Use repetition as a barrier}

The explicit repetition of shared components can be used to introduce a barrier into a coordinated phrase in order to prevent attachment to the elements on the other side of the barrier.

This drafting rule thus offers yet another way to express reading (9-c)
C: Das Bundesgericht deckt seinen Bedarf an Gütern und seinen Be- darf an Dienstleistungen im Bereich der Logistik selbständig.
'The Federal Supreme Court covers its need for goods and its need for services in the sector of logistics autonomously.'
E: Das Bundesgericht deckt seinen Bedarf an Gütern und seinen Be- darf an [ Dienstleistungen im Bereich der Logistik ] selbständig.
'The Federal Supreme Court covers its need for goods and its need for [services in the sector of logistics ] autonomously.'

R: Das Bundesgericht deckt seinen Bedarf an Gütern sowie seinen Bedarf an Dienstleistungen im Bereich der Logistik selbständig.

'The Federal Supreme Court covers its need for goods as well as its need for services in the sector of logistics autonomously.'

To be as explicit as possible, the recommended wording suggests that the repetition of shared components is combined with the use of sowie instead of und.

The last reading, (9-d), is not so easy to generate within the proposed rules. There is no position at which the prepositional phrase im Bereich der Logistik would unequivocally be attached to Bedarf; the only possible one, the one immediately after Bedarf, is already occupied by the prepositional phrase an Gütern und Dienstleistungen. Thus, a more substantial rephrasing is needed. Reading (9-d) can, for instance, be obtained by transforming the prepositional phrase in question into an attributive structure that precedes the phrase it modifies:

(16) C: Das Bundesgericht deckt seinen im Bereich der Logistik vorhandenen Bedarf an Gütern und Dienstleistungen selbständig.

'The Federal Supreme Court covers its logistics-related need for goods and services autonomously.'

E: Das Bundesgericht deckt seinen [ im Bereich der Logistik vorhandenen Bedarf ] an [ Gütern und Dienstleistungen ] selbständig. 'The Federal Supreme Court covers its [ logistics-related need ] for [ goods and services ] autonomously.' 
R: Das Bundesgericht deckt seinen im Bereich der Logistik vorhandenen Bedarf an Gütern und Dienstleistungen selbständig.

'The Federal Supreme Court covers its logistics-related need for goods and services autonomously.'

This rephrasing strategy has led to another drafting rule:

\section{Rule 4. Rephrase multiple attachments I}

If two prepositional phrases should be attached to the same noun phrase, one has to be rephrased as an adjectival or participial attribute.

In the discussed example (8), only two prepositional phrases where involved. What to do if more than two occur in the same sentence? Even in the short example we had problems to achieve reading (9-d), where both prepositional phrases had to attach to the same constituent. With more prepositional phrases occurring, the intended attachments often cannot be satisfactorily resolved through basic means such as shifting of the prepositional phrase next to the modified constituent 11 A more thorough paraphrasing step is needed. Take, for instance, the following sentence from the Swiss Federal Supreme Court Act 12

In Fünferbesetzung entscheiden sie ferner über Beschwerden gegen referendumspflichtige kantonale Erlasse und gegen kantonale Entscheide über die Zulässigkeit einer Initiative oder das Erfordernis eines Referendums.

'In a composition of five, they further decide on appeals against cantonal decrees that are subject to referendum and against cantonal decisions on the admissibility of an initiative or the necessity of a referendum.'

The nesting of multiple prepositional phrases in this sentence gives rise to a range of interdependent attachment ambiguities. The main problem is that entscheiden über, entscheiden gegen and entscheiden + noun phrase are all valid constructions and every coordinated item can theoretically be attached to the verb. On the other hand, they can also be attached to Beschwerden. The attachment of the last noun phrase (das Erfordernis eines Referendums) is particularly unclear: is it coordinated with Zulässigkeit einer Initiative and therefore attached to Entscheide (über), or is it coordinated with the long prepositional phrase über Beschwerden ... einer Initiative and thus attached to the verb? Such a sentence is not only hard to parse but also difficult to understand: many combinations of attachment can only be ruled out if appropriate context knowledge is accessible.

$\overline{11}$ Interpretation rule 1 does, for example, not cover constructions where the prepositional phrase itself is a coordinated structure: the conjuncts could either (i) both separately modify the governing constituent or (ii) modify the governing constituent as a whole. Additionally, with multiple nested coordinations, it must be decided which items are mutually coordinated: ' $\mathrm{x}$ and (y or z)' vs. '( $\mathrm{x}$ and $\mathrm{y}$ ) or $\mathrm{z}$ '.

12 Art. 20 Abs. 3 Bundesgerichtsgesetz. 


\section{Rule 5. Rephrase multiple attachments II}

Use an enumeration (1) if there are four or more elements to a coordination or (2) if the elements of the coordination are long, e.g. consist of noun phrases with complex attributes, or (3) if the attachment of prepositional phrases according to rules 14 results in a cumbersome wording.

Example (18) illustrates what the sentence looks like if it is rephrased according to the rules we introduced. We do not show the recommended version as it uses the same wording as the conventional version.

(18) C: In Fünferbesetzung entscheiden sie ferner über Beschwerden gegen:

a. referendumspflichtige kantonale Erlasse;

b. kantonale Entscheide über die Zulässigkeit einer Initiative;

c. kantonale Entscheide über das Erfordernis eines Referendums.

'In a composition of five, they further decide on appeals against:

a. cantonal decrees that are subject to referendum;

b. cantonal decisions on the admissibility of an initiative;

c. cantonal decisions on the necessity of a referendum.'

E: In Fünferbesetzung entscheiden sie ferner über Beschwerden gegen:

a. referendumspflichtige kantonale Erlasse;

b. kantonale Entscheide [ über die Zulässigkeit einer Initiative ];

c. kantonale Entscheide [ über das Erfordernis eines Referendums ].

'In a composition of five, they further decide on appeals against:

a. cantonal decrees that are subject to referendum;

b. cantonal decisions [ on the admissibility of an initiative ];

c. cantonal decisions [ on the necessity of a referendum ].'

As the example shows, explicit enumerations remove a large number of attachment ambiguities from sentences with complex, nested coordination structures and thus make them easier to read and understand.

\subsection{Controlling Plural Ambiguities}

Authors often find it hard to spot plural ambiguities contained in their texts; yet this particular type of semantic ambiguity is not only prevalent in legislative writing [1] but can indeed lead to confusions with regard to the meaning of a passage, as the following example illustrates 13

$\overline{13}$ This genuine example is taken from a draft of the Swiss Regulation on Immigration and Visa Granting (Art. 6 Abs. 3 Bst. e VEV). 
[Von der Visumpflicht sind ausgenommen:]

e. Inhaberinnen und Inhaber eines [...] Sonderpasses, der von den in Absatz 2 genannten Staaten ausgestellt wurde;

'[Exempt from the visa requirement are:]

e. owners of a special passport that was issued by the states mentioned in paragraph 2;'

Due to plural ambiguity, the correct interpretation of the noun phrase eines Sonderpasses, der von den [...] genannten Staaten ausgestellt wurde ('a special passport that was issued by the states mentioned [...]') is uncertain; it can have at least the following meanings:
a. 'a special passport that was issued by one of the states mentioned' (singular reading)
b. 'a special passport that was issued by all of the states mentioned together' (collective plural reading)
c. 'a special passport that was issued by each of the states mentioned individually' (distributive plural reading)

Reading (20-a) does not interpret the noun phrase die genannten Staaten ('the states mentioned') as a plural at all: it rather assumes that the plural form of that noun phrase is merely a projection from Inhaberinnen und Inhaber ('owners'), in whose scope it appears. Readings (20-b) and (20-c), in contrast, represent the classical distributive and collective plural interpretations, as described e.g. in [27. In legislative texts, this classical plural ambiguity seems seldom of great consequence: normally, world knowledge prevents a wrong interpretation, or the distinction between a collective and a distributive reading is not relevant in the first place and can thus be left underspecified. The distinction between a singular and a plural interpretation, on the other hand, can prove to be critical for the correct application of a statute or regulation.

Existing drafting guidelines such as 21] consequently suggest that reading $(20-\mathrm{a})$ should be expressed by a singular rather than a plural. We have incorporated this guideline:

\section{Rule 6. Use singular forms for singular objects}

A singular form should be used to refer to a singular object, even if it occurs within the scope of a plural object.

Instead of an indefinite plural noun phrase, use an indefinite singular noun phrase; instead of a definite plural noun phrase, use eine $/ r / s$ der and that plural noun phrase. 
The present example would thus have to be rephrased by replacing the plural die genannten Staaten ('the states mentioned') with einer der genannten Staaten ('any/one of the states mentioned') if reading (20-a) was intended 14

(21) C: Inhaberinnen und Inhaber eines Sonderpasses, der von einem der in Absatz 2 genannten Staaten ausgestellt wurde

'owners of a special passport that was issued by any of the states mentioned in paragraph 2 '

E: jede Inhaberin und jeder Inhaber eines Sonderpasses, der von einem der in Absatz 2 genannten Staaten ausgestellt wurde

'every owner of a special passport that was issued by any of the states mentioned in paragraph 2'

R: Inhaberinnen und Inhaber eines Sonderpasses, der von einem der in Absatz 2 genannten Staaten ausgestellt wurde

'owners of a special passport that was issued by any of the states mentioned in paragraph 2 '

Note that the recommended version is identical to the drafted conventional version. The explicit paraphrase only has to make the interpretation of the subject explicit (see below); the noun phrase in question is unambiguous now 15

The method controlled natural languages typically choose to control the ambiguity of 'real' plural noun phrases is to use markers such as je ('each') and gemeinsam ('together') to distinguish between distributive and collective readings [27. However, as these markers do not modify the noun phrases in question but rather the verb, the derivation of explicit paraphrases and recommended wordings would not be trivial. We have thus chosen to take a different approach by constructing drafting rules that are based on (i) existing frequency distributions and (ii) conventions already present in legislative language.

Our analysis of several legislative texts has shown that distributive interpretations of plural noun phrases clearly occur more often than collective readings. We have thus constructed a drafting rule that reflects this fact:

\section{Rule 7. Use plurals distributively}

Plurals should only be used in the distributive sense.

Example (19) illustrates how the usage requested by this rule is made explicit and what wording is recommended for it:

${ }^{14}$ It is indeed the intended reading as showed by the final and published version of the Swiss Regulation on Immigration and Visa Granting (Art. 6 Abs. 3 Bst. e VEV). The unclear passage was corrected by the Central Language Services during their reviewing process.

15 Theoretically, there still is a scope ambiguity: do the owners of a special passport each have their own passport or is there one specific passport that they all share? In the context of legislative texts, the interpretation where the existential quantified phrase gets wide scope without specifically being marked is very improbable and is a mere theoretical possibility. 
C: Inhaberinnen und Inhaber eines Sonderpasses, der von den in Absatz 2 genannten Staaten ausgestellt wurde

'owners of a special passport that was issued by the states mentioned in paragraph 2'

E: jede Inhaberin und jeder Inhaber eines Sonderpasses, der von jedem der in Absatz 2 genannten Staaten ausgestellt wurde

'every owner of a special passport that was issued by each of the states mentioned in paragraph 2'

R: Inhaberinnen und Inhaber eines Sonderpasses, der von jedem der in Absatz 2 genannten Staaten ausgestellt wurde

'owners of a special passport that was issued by each of the states mentioned in paragraph 2 '

The distributive reading is made explicit by inserting jeder der ('each of the') in front of the definite plural noun phrase. This paraphrase sounds more or less natural and can be used in situations where it is essential to be precise and no general world-knowledge prevents unwanted interpretations. It is therefore also used in the recommended version.

Note that the subject of the sentence, Inhaberinnen und Inhaber ('owners'), is a plural noun phrase too and could thus also produce plural ambiguity. In the paraphrase, the distributive usage recommended by the drafting rule is made explicit by the insertion of jeder ('every') in front of it 16

To express the collective reading (20-b), we have adopted a convention that already exists in legislative language: the use of abstract singular terms instead of plurals. Legislative texts frequently coin and employ collective singular nouns such as das Gericht ('the court'), die Erbengemeinschaft ('the community of heirs') or die Inhaberschaft ('the ownership'). We have thus defined the following drafting rule:

\section{Rule 8. Use singular terms for collective readings}

To express collective plural readings, abstract singular terms should be used.

Example (23) illustrates how this rule can be applied. The collective plural reading of sample sentence (19) is achieved by the singular term die Staatengemeinschaft ('the community of states'):

C: Inhaberinnen und Inhaber eines Sonderpasses, der von der in Absatz 2 genannten Staatengemeinschaft ausgestellt wurde

'owners of a special passport that was issued by the community of the states mentioned in paragraph 2 '

${ }^{16}$ We have argued elsewhere that, in legislative texts, indefinite noun phrases in vorfeld position can be considered to be implicitly universally quantified [10. Legislative texts state rules that apply to a certain group or set of objects. In Swiss Germanlanguage legislative texts, this subject matter of a norm is usually mentioned in the vorfeld position and must be interpreted in a definitional generic sense. 
E: jede Inhaberin und jeder Inhaber eines Sonderpasses, der von der in Absatz 2 genannten Staatengemeinschaft ausgestellt wurde 'every owner of a special passport that was issued by the community of the states mentioned in paragraph 2'

R: Inhaberinnen und Inhaber eines Sonderpasses, der von der in Absatz 2 genannten Staatengemeinschaft ausgestellt wurde

'owners of a special passport that was issued by the community of the states mentioned in paragraph 2 '

Because of the use of a singular term, the noun phrase in question is not ambiguous anymore. The explicit paraphrase thus only needs to make the interpretation of the subject of the sentence explicit, and the recommended wording is identical to the original conventional formulation.

\section{Related Work}

Ambiguity in law has been studied by several researchers, for the Anglo-American legal system for example by Lawrence Solan [3132] and Sanford Schane [2324]. Government agencies and organizations such as the Plain English or Plain Language initiative 17 have addressed the problem in a fashion that is broadly similar to the aforementioned guidelines [26 256 5 218]. However, these drafting manuals typically formulate general rules - for example, that the active voice should be used or sentences should be short. They do not cover rules that require deeper linguistic insight, although this would be desirable: Carl Vogel [36] presents a study of statutory drafting in Ireland in which he argues that it is particularly with regard to issues of natural language ambiguity that linguistics (and formal semanticists) can make a pivotal contribution to legislative drafting.

Regarding controlled languages, there have only been very few attempts to design controlled versions of German: "Siemens Dokumentationsdeutsch" [14 and "Controlled German" 13. All these attempts were concerned with technical language, and, as far as we know, remained research prototypes. No effort has been made to transfer these attempts to legal language, but some of the rules could also be applied to legal texts.

Every authoring tool for controlled natural languages has to make the actual interpretation explicit and doing this by paraphrasing ambiguous constructions is not a new idea. It has been done in several approaches, for example for ACE [12, PENG 29] and IBM's Easy English 3. However, the mentioned approaches rely on a complete grammar and generate the paraphrases automatically. In contrast, our rules are guidelines for humans. They are intended to help the drafter choose a sensible phrasing and to make legislative texts more consistent by establishing new interpretation rules 18 Establishing interpretation rules for specific constructions

\footnotetext{
17 http://www.plainenglish.co.uk, http://www.plainlanguage.gov

18 Some of our rules discussed in this paper have already had an impact on the drafting process: there has been a thorough discussion about the proper use of "sowie" vs. "und" 4.
} 
is indeed quite common in the legal domain: interpretation principles are accepted as a means to support deciding ambiguous or vague cases 3624 .

\section{Conclusion}

In this paper, we have shown how the methods of controlled natural language can be applied to reduce ambiguity in legislative texts. We have introduced a three-layer approach, in which we specify drafting rules for specific ambiguous constructions. Sentences that are formulated according to these rules can be transformed deterministically into pre-defined explicit paraphrases and recommended wordings. At the moment, this transformation has to be done by hand. However, the availability of deterministic mechanisms as proposed in this paper constitutes a precondition for a future automatic processing. The proposed drafting rules are designed to reflect conventions and frequency distributions that already exist in legislative language and to exploit guidelines that have already been issued by various government agencies. We have argued that two types of ambiguity are in need of such additional control: attachment ambiguity and plural ambiguity. Not only are these insufficiently covered by existing drafting guidelines but they are also particularly frequent in legislative texts and prone to causing problems for the correct interpretation of a statute or regulation.

A thorough application of drafting rules like the ones proposed in this paper has several benefits: it helps drafters become aware of ambiguities hidden in their texts, it helps them formulate sentences that are easier to understand and finally, it can lead to a greater standardization of legislative language, especially with regard to the phenomenon of ambiguity. Such a standardization can facilitate the interpretation of legislative texts but it can also support their translation into other languages - an aspect which is particularly relevant for multilingual countries like Switzerland or for international organizations like the European Union.

\section{References}

1. Adams, K.A., Kaye, A.S.: Revisiting the ambiguity of "And" and "Or" in legal drafting. St. John's Law Review 80(4) (2006)

2. ASD: ASD Simplified Technical English: Specifications ASD-STE100. AeroSpace and Defence Industries Association of Europe, Simplified Technical English Maintenance Group (ASD STEMG) (2005)

3. Bernth, A.: EasyEnglish: A tool for improving document quality. In: Proceedings of the Fifth Conference on Applied Natural Language Processing, pp. 159-165. Association for Computational Linguistics, Morriston (1997)

4. Bratschi, R.: "und" vs. "sowie". Redaktionsbeispiel vom 19 (August 2010) (unpublished)

5. Caussignac, G., Eberhard, C., Häusler, P., Kettiger, D., Pulitano, D., Schneider, R.: Rechtsetzungsrichtlinien des Kantons Bern, Modul 3: Rechtsetzungstechnische Richtlinien (RTR). Justiz-, Gemeinde- und Kirchendirektion und Staatskanzlei des Kantons Bern, Bern (2000)

6. Caussignac, G., Eberhard, C., Häusler, P., Kettiger, D., Pulitano, D., Schneider, R.: Rechtsetzungsrichtlinien des Kantons Bern, Modul 4: Sprache. Justiz-, Gemeindeund Kirchendirektion und Staatskanzlei des Kantons Bern, Bern (2000) 
7. Clark, P., Harrison, P., Jenkins, T., Thompson, J., Wojcik, R.: Acquiring and using world knowledge using a restricted subset of English. In: FLAIRS 2005, pp. 506-511 (2005)

8. Europäische Kommission, Luxemburg, Amt für amtliche Veröffentlichungen der Europäischen Gemeinschaften: Gemeinsamer Leitfaden des Europäischen Parlaments, des Rates und der Kommission für Personen, die in den Gemeinschaftsorganen an der Abfassung von Rechtstexten mitwirken (2003), http://eur-lex.europa.eu/de/techleg/index.htm

9. Fuchs, N.E., Kaljurand, K., Kuhn, T.: Attempto Controlled English for Knowledge Representation. In: Baroglio, C., Bonatti, P.A., Małuszyński, J., Marchiori, M., Polleres, A., Schaffert, S. (eds.) Reasoning Web 2008. LNCS, vol. 5224, pp. 104-124. Springer, Heidelberg (2008)

10. Hoefler, S., Bünzli, A.: Controlling the language of statutes and regulations for semantic processing. In: Proceedings of the LREC 2010 Workshop on Semantic Processing of Legal Texts (SPLeT 2010), Valletta, Malta, pp. 8-15 (2010)

11. Iluk, J.: Die Verständlichkeit der deutschen, österreichischen, schweizerischen und polnischen Verfassung, Versuch einer komparatistischen Analyse. In: EichhoffCyrus, K.M., Antos, G. (eds.) Verständlichkeit als Bürgerrecht? Die Rechts- und Verwaltungssprache in der öffentlichen Diskussion, pp. 136-154. Dudenverlag, Mannheim (2008)

12. Kaljurand, K.: Paraphrasing controlled English texts. In: Fuchs, N.E. (ed.) PreProceedings of the Workshop on Controlled Natural Language (CNL 2009). CEUR Workshop Proceedings, vol. 448, CEUR-WS (April 2009)

13. Lehrndorfer, A.: Kontrolliertes Deutsch. Linguistische und sprachpsychologische Leitlinien für eine (maschinell) kontrollierte Sprache in der Technischen Dokumentation. No. 415 in Tübinger Beiträge zur Linguistik, Gunter Narr Verlag, Tübingen (1996)

14. Lehrndorfer, A., Schachtl, S.: Controlled Siemens Documentary German and TopTrans. Technical Communicators Forum 3 (1998)

15. Lötscher, A.: Multilingual law drafting in Switzerland. In: Grewendorf, G., Rathert, M. (eds.) Formal Linguistics and Law. Trends in Linguistics. Studies and Monographs, pp. 371-400. Mouton de Gruyter, Berlin (2009)

16. Nussbaumer, M.: Zwischen Rechtsgrundsätzen und Formularsammlung: Gesetze brauchen (gute) Vagheit zum Atmen. In: Bhatia, V.K., Engberg, J., Gotti, M., Helier, D. (eds.) Vagueness in Normative Texts, Linguistic Insights. Studies in Language and Communication, vol. 23, pp. 49-71. Peter Lang, Bern (2005)

17. Nussbaumer, M.: Rhetorisch-stilistische Eigenschaften der Sprache des Rechtswesens. In: Fix, U., Gardt, A., Knape, J. (eds.) Rhetorik und Stilistik / Rhetoric and Stylistics. Ein Internationales Handbuch Historischer und Systematischer Forschung / An International Handbook of Historical and Systematic Research, Handbücher zur Sprach- und Kommunikationswissenschaft / Handbooks of Linguistics and Communication Science / [HSK] 31/2, ch. 128, vol. 2 (Halbband), pp. 2132-2150. Mouton de Gruyter (2009)

18. O'Brien, S.: Controlling controlled English: An analysis of several controlled language rule sets. In: EAMT-CLAW-2003, pp. 105-114, Controlled language translation (2003)

19. Pace, G.J., Rosner, M.: A Controlled Language for the Specification of Contracts. In: Fuchs, N.E. (ed.) CNL 2009. LNCS, vol. 5972, pp. 226-245. Springer, Heidelberg (2010)

20. Pool, J.: Can controlled languages scale to the web? In: CLAW 2006 at AMTA 2006: 5th International Workshop on Controlled Language Applications (2006) 
21. Regierungsrat des Kantons Zürich: Richtlinien der Rechtsetzung (2005)

22. Reuther, U.: Two in one - can it work? Readability and translatability by means of controlled language. In: Proceedings of EAMT-CLAW (2003)

23. Schane, S.: Ambiguity and misunderstanding in the law. T. Jefferson L. Rev. 25, 167-649 (2002)

24. Schane, S.A.: Language and the law. Continuum International Publishing Group (2006)

25. Schweizerische Bundeskanzlei, in Zusammenarbeit mit der Zürcher Hochschule für Angewandte Wissenschaften: Geschlechtergerechte Sprache. Leitfaden zum geschlechtergerechten Formulieren im Deutschen, 2 edn. (2009)

26. Schweizerisches Bundesamt für Justiz, Bern: Gesetzgebungsleitfaden: Leitfaden für die Ausarbeitung von Erlassen des Bundes, 3 edn. (2007)

27. Schwertel, U.: Controlling plural ambiguities in Attempto Controlled English. In: Proceedings of the 3rd International Workshop on Controlled Language Applications, Seattle, Washington (2000)

28. Schwitter, R., Tilbrook, M.: Let's talk in description logic via controlled natural language. In: Proceedings of the 3rd International Workshop on Logic and Engineering of Natural Language Semantics, Tokyo, pp. 193-207 (2006)

29. Schwitter, R., Ljungberg, A., Hood, D.: ECOLE - a look-ahead editor for a controlled language. In: Proceedings of EAMT-CLAW 2003, pp. 141-150 (2003)

30. Schwitter, R., Tilbrook, M.: Annotating websites with machine-processable information in controlled natural language. In: Proceedings of the Second Australasian Workshop on Advances in Ontologies, AOW 2006, vol. 72, pp. 75-84. Australian Computer Society, Inc., Darlinghurst (2006)

31. Solan, L.M.: Linguistic principles as the rule of law. In: Pupier, P., Woehrling, J. (eds.) Language and Law: Proceedings of the First Conference of the International Institute of Comparative Linguistic Law. Wilson \& Lafleur, Montreal (1989)

32. Solan, L.M.: Vagueness and ambiguity in legal interpretation. In: Bhatia, V.K., Engberg, J., Gotti, M., Helier, D. (eds.) Vagueness in Normative Texts, Linguistic Insights. Studies in language and Communication, vol. 23, pp. 73-96. Peter Lang, Bern (2005)

33. Sowa, J.F.: Common logic controlled English, draft, March 15 (2007), http://www.jfsowa.com/clce/clce07.htm

34. Venturi, G.: Parsing legal texts. A contrastive study with a view to knowledge management applications. In: LREC 2008 - W9 Workshop on Semantic Processing of Legal Texts (2008)

35. Verbeke, C.: Caterpillar Fundamental English. A basic approach for multination technical communication in an industry basic approach for multination technical communication in an industry. Training and Development Journal 27(2), 36-40 (1973)

36. Vogel, C.: Law matters, syntax matters and semantics matters. In: Grewendorf, G., Rathert, M. (eds.) Formal Linguistics and Law, Trends in Linguistics. Studies and Monographs, vol. 212, pp. 25-54. Mouton de Gruyter, Berlin (2009) 